\title{
Primary breast angiosarcoma in postmenopausal woman: case study and the literature review
}

\section{Pierwotny naczyniakomięsak piersi u chorej po menopauzie: prezentacja przypadku i przegląd piśmiennictwa}

\author{
Joanna Jońska-Gmyrek¹, Elwira Bakuła-Zalewska², Jacek Gałecki', Agnieszka Żółciak-Siwińska², \\ Leszek Gmyrek ${ }^{4}$
}

\begin{abstract}
'Department of Radiotherapy. The Maria Sklodowska-Curie Memorial Cancer Center and Institute of Oncology, Warsaw, Poland; Head of Department: Prof. Krzysztof Bujko MD, PhD

${ }^{2}$ Department of Pathology, The Maria Sklodowska-Curie Memorial Cancer Center and Institute of Oncology, Warsaw, Poland; Head of Department: Prof. Jolanta Kupryjańczyk MD, PhD

${ }^{3}$ Department of Brachytherapy. The Maria Sklodowska-Curie Memorial Cancer Center and Institute of Oncology, Warsaw, Poland; Head of Department: Anna Kulik MD, PhD

${ }^{4}$ Department of Gynecological Oncology. Holy Family Hospital, Warsaw, Poland;

Head of Department: Prof. Bogdan Chazan MD, PhD
\end{abstract}

Przegląd Menopauzalny 2013; 17 (5): 438-441

\section{Summary}

A case of an 83-year-old female patient, who was admitted to the Centre of Oncology in Warsaw because of the right breast tumor, is presented. There was no exposure to prior irradiation. In two biopsies of the lesion, its malignant nature was not confirmed. Breast tumor removal with wide surgical margins was performed. As a result of the examination, angiosarcoma was confirmed histologically. Given the result, a simple right breast amputation was performed. External beam radiotherapy and chemotherapy, due to the rapid local recurrence and distant metastases, were also performed. The patient died after 20 months of the initial diagnosis because of the disease progression.

Key words: breast angiosarcoma, pathology, symptoms, diagnosis, treatment.

\section{Streszczenie}

Przedstawiono przypadek 83-letniej kobiety, która zgłosiła się do Centrum Onkologii w Warszawie z powodu guza piersi prawej. W wywiadzie nie stwierdzono wcześniejszej ekspozycji na promieniowanie jonizujące. W trakcie dwukrotnie wykonanych biopsji nie potwierdzono złośliwego charakteru zmiany. Przeprowadzono wycięcie guza piersi z szerokim marginesem. W wyniku badania histopatologicznego potwierdzono utkanie naczyniakomięsaka. Ze względu na uzyskany wynik przeprowadzono prostą amputację prawej piersi. W związku z wczesnym nawrotem miejscowym i przerzutami odległymi, pacjentka została zakwalifikowana do radioterapii i chemioterapii. Chora zmarła po upływie 20 miesięcy od rozpoznania choroby z powodu progresji.

Słowa kluczowe: naczyniakomięsak piersi, patologia, objawy, diagnoza, leczenie.

\section{Introduction}

Primary breast angiosarcoma is a rare tumor with an aggressive clinical course and constitutes about 0.04\% of all malignant lesions of the breast [1-10]. It occurs mainly in women in the $3-4^{\text {th }}$ decade of life $[4,11]$. In postmenopausal women, it is most common as a secondary process after exposure to ionizing radiation [3, 9]. Due to a very low incidence of primary breast angio- sarcoma in this group of women, only isolated cases have been presented in the literature $[2,4,8,12,13]$.

\section{Case report}

So far healthy, 83-year-old woman with one birth in a medical history, family history irrelevant, came to the Institute of Oncology in Warsaw with a tumor in the right 
breast and 11-month follow-up in the area. There was no exposure to prior ionizing radiation or chronic lymphatic stasis. In the physical examination, there was a palpable tumor on the border of the upper quadrants of the right breast with a diameter of $55 \mathrm{~mm}$. The lymph nodes were not suspicious.

The material collected during two biopsies of the tumor did not confirm the malignant nature of the lesion. Removal of the right breast tumor with a wide margin was performed (Fig. 1). Pathological results were as follows: breast angiosarcoma (Fig. 2).

Due to the result, a simple right breast mastectomy was performed. Microscopic examination revealed a diffuse, irregular dilated network exhibiting atypical proliferation of endothelial cells. In the immunohistochemical study, the tumor cells showed positive staining for factor VIII (von Willebrand factor - vWF) (Fig. 3) and the expression of CD 31 (Fig. 4). The angiosarcoma cells were also confirmed in the wall of the lodge.

Two weeks after the mastectomy, a scar recurrence was observed. Surgical excision of the infiltration was done. The patient was qualified for radiotherapy. Irradia-

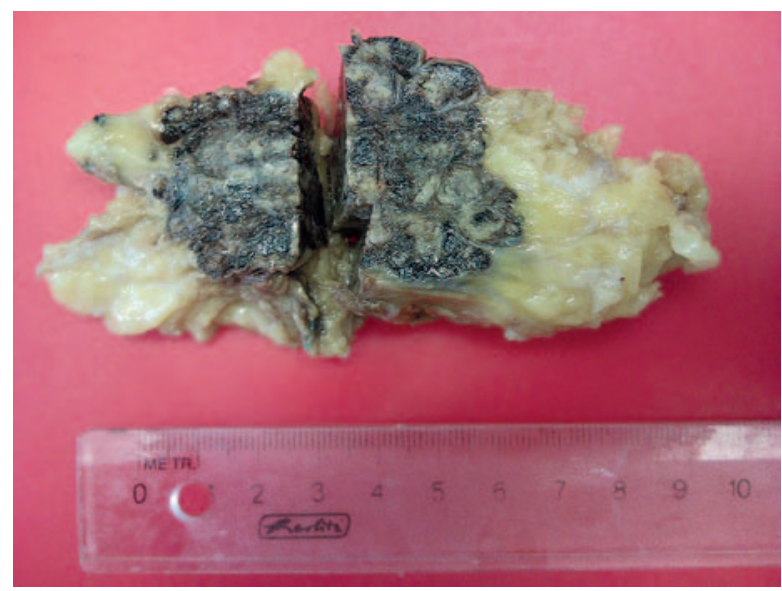

Fig. 1. Macroscopic view of the specimen

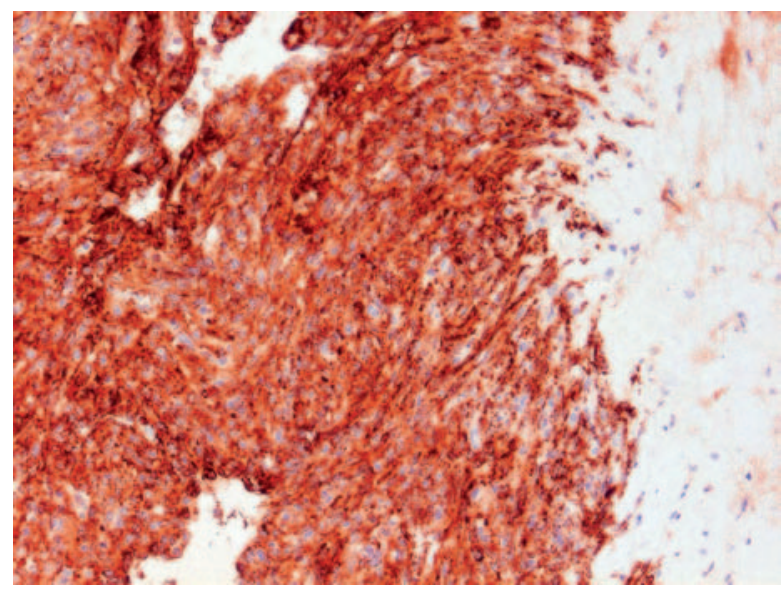

Fig. 3. Factor VIII staining tion was performed in the area of the chest wall using electrons with an energy of $9 \mathrm{MeV}$ (megaelectron volt), to a total dose of 60 Gy (Grey)/90\% in 30 fractions over 6 weeks. At the end of irradiation the patient reported back pain.

Magnetic resonance imaging (MRI) was carried out. The investigation confirmed spine metastases in the thoracic-lumbar vertebrae penetrating into the spinal canal. Palliative radiotherapy was performed. During the following month, metastases to bones of the forearm, left clavicle and left iliac were confirmed.

The patient was irradiated again with a very good analgesic effect. After a month, the abdominal CT and chest revealed multiple metastases to the liver and lungs. The patient was qualified for chemotherapy. The disease had progressed during the treatment. The patient died after 20 months of the initial diagnosis because of the disease progression.

\section{Discussion}

The case relates to the original, very rare in the postmenopausal period, breast angiosarcoma with a very

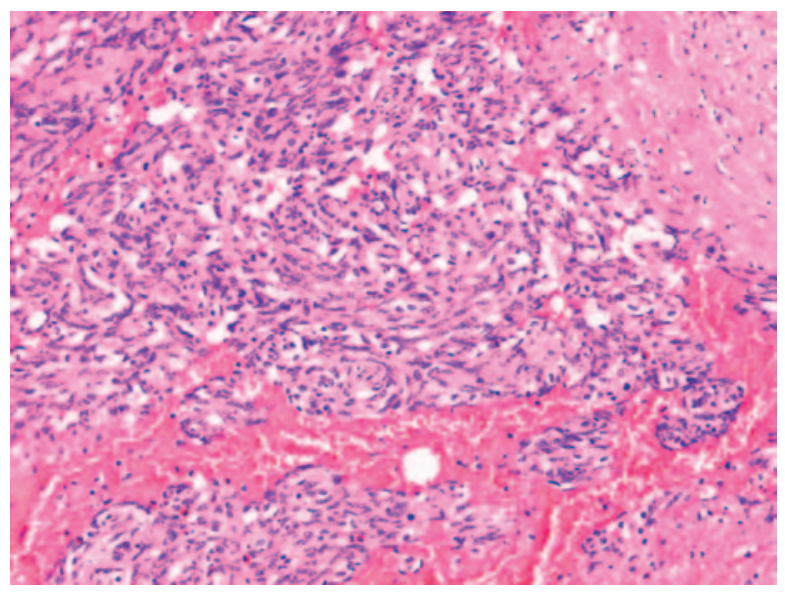

Fig. 2. Microscope image of angiosarcoma

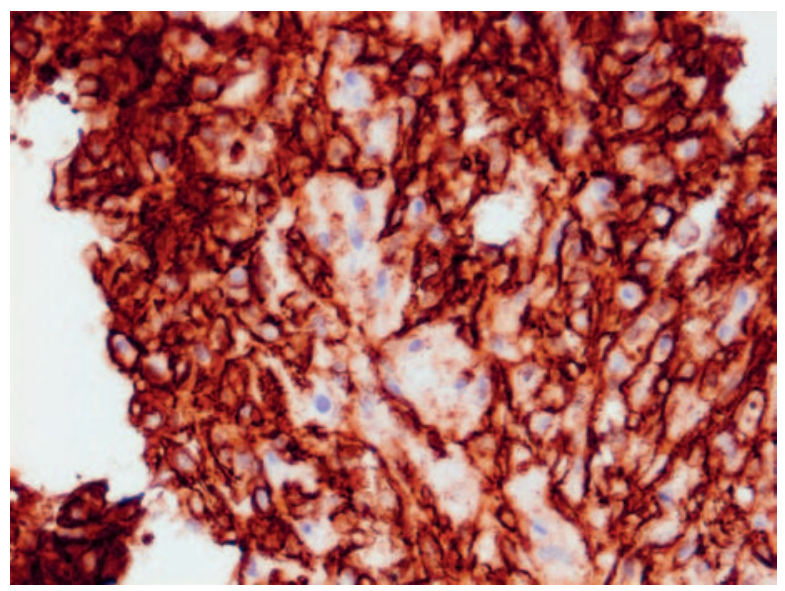

Fig. 4. CD 31 staining 
aggressive course in an 83-year-old woman. An interesting fact is the excellent analgesic response to palliative radiotherapy for bone metastases.

Primary breast angiosarcoma is most common in the $3-4^{\text {th }}$ decade of life $[3,10,11]$. It usually occurs sporadically, with no specific etiologic factor [2, 3]. In postmenopausal women, it most often occurs as a result of previous irradiation or chronic lymphatic stasis in the vessels, especially after the conserving surgery for breast cancer, but is rare as the primary malignancy in these women [2, 3, 14].

The preferred diagnostic method in the case of larger tumors is the core biopsy, while for tumors of smaller dimensions, it is the surgical excision with a wide margin and examination of the removed material $[12,14]$.

In the presented case, the observation of a small tumor in the breast, characterized by a very dynamic growth and a slight discoloration, lasted for 11 months. Then, in a double-collected material, the malignant nature of the tumor was not confirmed. As a result of the situation, the final diagnosis was confirmed one year after the tumor appeared.

Such a long diagnostic process in this case, when compared to the literature data, is not isolated. The clinical course of angiosarcoma presented in the literature varies. Some authors describe the symptoms as a large-sized tumor with rapid growth $[4,10,11]$, others suggest that it is a small, irregular mass causing a feeling of fullness and swelling of the breasts, and still others as a small bump of a bluish-red color with the appearance of hematoma, sometimes presenting growth acceleration [14]. Very often these tumors are observed for some time, as in the presented patient.

There are also two cases of angiosarcoma described in the literature, in which the first symptom was severe thrombocytopenia and bleeding [10].

Scow et al. presented a primary angiosarcoma occurring in the form of a tumor, and the secondary as redness of the skin [15].

The clinical course of angiosarcoma described in the literature is similar, regardless of the etiological agent [11].

Sher et al. drew attention to the aggressive clinical course of the disease and a tendency to local recurrence [16]. For the actually presented patient, the postoperative scar recurrence occurred within two weeks after the mastectomy.

Histopathological diagnosis of angiosarcoma is very difficult [13]. It often happens that, as in the presented case, a biopsy does not confirm the malignant nature of the tumor. Diverse clinical course and diagnostic problems are probably the result of different histological subtypes. Glazebrook et al. and Kaklamanos et al. describe three different histological subtypes of angiosarcoma:

- I - including vascular channels infiltrating breast fat and parenchyma, with little or no proliferation of endothelial cells,
- II - containing lesions of solid growth and vascular papillary - endothelial component,

- III - growth of pure sarcoma with solid components of endothelial bloody strokes and necrosis $[3,10]$.

Lilai et al. divided angiosarcoma into two subtypes: well-differentiated and undifferentiated. The authors concluded that the prognosis was closely related to the degree of histological differentiation [11].

Imaging diagnosis of angiosarcoma, due to the nonspecific image, is also very difficult. The results of mammography and ultrasonography may suggest the presence of benign lesions. MRI is a useful test [3, 12].

The principal therapeutic method is surgery $[1,2,10$, $11,14]$. However, there is a controversy over the surgical treatment. Some authors believe that the excision of the tumor with a $1 \mathrm{~cm}$ margin is sufficient, while others offer $3 \mathrm{~cm}$ [14], but most of them propose a simple mastectomy without axillary lymph node dissection, due to the fact that most angiosarcoma tumors disseminate through the blood system $[2,11,14,15]$.

It is believed that adjuvant therapy, involving the use of chemotherapy in these patients, improves survival. However, further studies are required [10].

Despite the lack of effect on overall survival, it has been shown that additional radiation contributes to the reduction in local recurrences $[2,10]$.

With early detection and appropriate method of treatment, survival of patients with breast angiosarcoma may be as high as $60-90 \%$ [14]. According to other authors, the survival can be $8-50 \%$ [2]. Survival of these patients is dependent on the following factors: tumor size, width of the surgical margins, age and general condition. Prognostic value of histological differentiation of the tumor in patients with angiosarcoma is a subject of controversy [2, 11].

The above-described diagnostic difficulties highlight the tremendous value of close collaboration between the clinician, pathologist and radiologist.

\section{Conclusions}

Primary angiosarcoma of the breast in postmenopausal women is rare. Diagnostic difficulties and the unusual image often lead to the delayed diagnosis and treatment, which results in lower curability. Oncological vigilance, whenever there are any new lesions, is extremely important.

\section{References}

1. Grodecka-Gazdecka S, Gryczka R, Otworowski A, Wygralak H. Rzadkie nowotwory gruczołu piersiowego - angiosarcoma. Przegl Gin Pol 2008; 8: 57-60.

2. Rohan VS, Hanji AM, Patel JJ, Tankshali RA. Primary angiosarcoma of the breast in a postmenopausal patient. J Can Res Ther 2010; 6: 120-2.

3. Glazebrook KN, Magut MJ, Reynolds C. Angiosarcoma of the breast. AJR Am J Roentgenol 2008; 190: 533-8. 
4. Farrokh D, Hashemi J, Zandi B. Angiosarcoma of the breast. Report of a case and literature review. Iran J Radiol 2006; 3: 81-4.

5. Vorburger SA, Xing Y, Hunt KK, et al. Angiosarcoma of the breast. Cancer 2005; 104: 2682-8.

6. Luini A, Gatti G, Diaz J, et al. Angiosarcoma of the breast: the experience of the European Institute of Oncology and review of the literature. Breast Cancer Res Treat 2007; 105: 81-5.

7. Nascimento AF, Raut CP, Fletcher CD. Primary angiosarcoma of the breast: clinicopathologic analysis of 49 cases, suggesting that grade is not prognostic. Am J Surg Pathol 2008; 32: 1896-904.

8. Zhou SA, Wei H, Ding K. A rare case of metachronous bilateral angiosarcoma of the breast. Breast Care (Basel) 2009; 4: 405-7.

9. Shet T, Malaviya A, Nadkarni M, et al. Primary angiosarcoma of the breast: Observations in Asian women. J Surg Oncol 2006; 94: 368-74.

10. Kaklamanos IG, Birbas K, Syrigos KN, et al. Breast angiosarcoma that is not related to radiation exposure: a comprehensive review of the literature. Surg Today 2011; 41: 163-8.
11. Lilaia C, Pereira F, André S, Cabrita B. Breast angiosarcoma. The Internet Journal of Gynecology and Obstetrics. 2007; 6 (2). DOI: 10.5580/4a.

12. Biswas $T$, Tang $P$, Muhs $A$, Ling $M$. Angiosarcoma of the breast: a rare clinicopathological entity. Am J Clin Oncol 2009; 32: 582-6.

13. Champeaux-Orange E, Bonneau C, Raharimanana B, et al. Primary breast angiosarcoma: two case reports. Cancer Radiother. 2009; 13: 209-12.

14. Mituś J, Wysocki W, Wojewoda T, Kojs Z. Rzadkie nowotwory złośliwe gruczołu piersiowego. Curr Gynecol Oncol 2011; 9: 38-46.

15. Scow JS, Reynolds CA, Degnim AC, et al. Primary and secondary angiosarcoma of the breast: the Mayo Clinic experience. J Surg Oncol 2010; 101: 401-7.

16. Sher T, Hennesy BT, Valero V, et al. Primary angiosarcoma of the breast. Cancer 2007; 110: 173-8. 